\title{
Literature-in-English as a Tool for Fostering Intercultural Communicative Competence in Multicultural Classrooms in Nigeria
}

\section{Oladotun Opeoluwa Olagbaju}

Department of Linguistic Education, College of Education \& Social Sciences, Legacy University, The Gambia.

dotunolagbaju@yahoo.com

\begin{abstract}
Nigeria is a nation of several unique ethnic nationalities with diverse cultures. Cultural diversity has been identified as one of the factors responsible for growing civil unrest, insecurity and hate speeches in different parts of Nigeria. Multiculturalism is a common experience in several Nigerian states and the Nigerian education system. Efforts to inculcate intercultural competence among the members of the numerous ethnic groups and cultural identities in the country have been in form of legislation, convocation of national conferences and certain 'political concessions' to different ethnic groups. In spite of these efforts, very little has been achieved. The concern of this study is to discuss how education, through the tool of literature-in-English, can be engaged to teach intercultural communicative competence in multicultural classrooms. Recommendations were made on how to use literature-inEnglish to facilitate cross-cultural competence in Nigeria.
\end{abstract}

Keywords

multiculturalism multilingualism intercultural competence; cultural diversity, literature-in-English

\section{Introduction}

Nigeria is unarguably one of the most populous nations in Africa with an estimated population of over 180 million people speaking over 500 languages fragmented into over 250 ethnic groups. The nation covers an area of 923,766 square kilometres that comprises 36 states and the Federal Capital Territory. Nigeria is heterogeneous in nature both linguistically and culturally and rather than leveraging on the cultural differences for gains in the area of national development; it has become a constant threat to national unity. Nigeria is a multicultural society and several aspects of the national life are influenced by conflicts based on differences in languages, cultures, religious and political affiliations. These unwarranted civil unrests among the many ethnic nationalities have dire implications for the national development and economic growth of the country. Ethnicity and language have been found to largely influence religious beliefs and activities in Nigeria (Blench \& Dendo, 2003). By extension, ethnicity and religion have significant implications for culture change and culture differences across Nigeria. 
Konfrontasi Journal: Culture, Economy and Social Changes, 7 (1) March 2020, 40-49

ISSN: 1410-881X (Print), 2716-2095 (Online)

Oladotun Opeoluwa Olagbaju: Literature-in-English as a Tool for Fostering Intercultural Communicative

Competence in Multicultural Classrooms in Nigeria

DOI: https://doi.org/10.33258/konfrontasi2.v7i1.95

http://www.konfrontasi.net/index.php/konfrontasi2

\section{Review of Literature}

\section{Need for Intercultural Communicative Competence in Nigeria through Education}

Most Nigerian societies, classrooms inclusive, are polarised along religious and ethnic divides and issues concerning religious and ethnic beliefs are common in the country. Blench and Dendo (2003) opine that although in principle, language, ethnicity and religion seem to be separate and unrelated entities, however most Nigerians, depending on their ethnic groups tend to either adopt Islam or Christianity (irrespective of denominations) as a mode of worship. According to Olagbaju (2014), any nation with access to more than a language in her day-to-day national experience is prone to conflict of linguistic and cultural dominance or identity especially in language contact situations. This is beca

luse the bond between language and culture is so strong that the former ultimately affects the latter. Common culture-related realities of such contact situations in Nigeria include culture shock, culture conflict, culture resistance, culture change, culture erosion, and multiculturalism.

Multiculturalism has serious implications for effective teaching and learning within and outside Nigerian classrooms. Lawal (2019) posits that instruction is mostly conducted in Nigerian pidgin English due to the multicultural nature of classrooms in most states of Southsouth Nigeria like Edo, Delta, Rivers, Bayelsa, Cross River and Akwa-lbom, classroom. This is because teachers are compelled by the necessity to improvise in the instructional delivery so that no learner will be left behind. Similarly, the content to be learned and choice of illustrations/examples must be seen to be devoid of ethnic or cultural bias. Therefore, the Nigerian Pidgin (NP) is widely used in certain states where minority languages abound without any particular language assigned as the major language (Lawal, 2019). To address the dilemma encountered by Nigerian teachers in multilingual/multicultural classrooms, the National Policy on Education (FGN, 2004:6) states:

The medium of instruction in the primary school shall be the language of the environment for the first three years. During this period, English shall be taught as a subject. From the fourth year, English shall progressively be used as a medium of instruction and the language of immediate environment and French shall be taught as subjects.

The excerpt from the Nigerian education policy quoted above affirms the reality of multilingualism/multiculturalism in the Nigerian classroom. Language plays a critical role in education and the NPE (as quoted above) has aptly addressed the multilingual challenges in the classroom. However, the policy has not adequately taken care of multiculturalism that exists in the Nigerian classroom that can impede effectiveness in teaching and learning. The relationship between language and culture is complementary because the language of a people serves as a vehicle for the preservation and transmission of their culture from one generation to the other. Multiculturalism, just like multilingualism, is a concrete experience in Nigeria and it is evident in every aspect of the nation's social life.

Cultural diversity has contributed significantly to the different aspects of the Nigerian national life. In Nigeria, cultures contact situations occur almost everywhere either in the classroom or the society at large. Ajitoni (2014) submits that cultural diversity threatens the peace, unity and corporate existence of Nigeria. Cultural differences are often exhibited as ethnic-based conflicts with religious colouration in Nigeria and this has largely become a prominent dividing feature in recent years Also, with the advent of globalisation and the concept of the world as a global village, there has been an increase in people's exposure to different cultures from Africa and beyond. Ajitoni and Salako (2012) reaffirm that competence in intercultural communication is inevitable in the 21 st century which signifies 
an era of increasing globalisation. Therefore, it is imperative that the Nigerians learn to communicate with people whose cultural heritage is vastly different from theirs.

Gómez (2012) avers that the goal of language instruction has gradually shifted to the development of intercultural communicative competence in learners over the last two decades. It is evident that teachers are becoming more conscious that the 21 st century learners as individuals with needs to be able to communicate in intercultural contexts and with people from different cultural backgrounds. Barrett, Byram, Lazar, Mompoint-Gaillard, and Philippou (2014) posit culture is dynamic and ever changing due to interaction with other cultures, will always have an impact on how members perceive themselves and how they view and interact with other people. The reality of culture contact situations within the classroom can no longer be denied especially with regards to the increase in fashion consciousness (tattoos, body piercing), choice of music genre, new knowledge of sexuality or sexual orientations, a new value system, youth restiveness, and so on. Other fallouts of multiculturalism in Nigeria include cultural prejudice, culture conflict, and culture transfer.

Similarly, issues regarding ethnic cum culture-related conflicts in Nigeria have led to protests on resource control, electoral violence, agitation for political power shift between Northern and Southern Nigeria, threats to national security across Nigeria caused by herdersfarmers' conflicts (Olagbaju \& Awosusi, 2019), and secession campaigns by IPOB in SouthEast Nigeria among others. To achieve communal peace across Nigeria and for the purpose of effective multicultural communication, intercultural or cross-cultural competence must be entrenched in the national consciousness of every Nigerian. Lustig and Koester (1996) assert that intercultural competence allows people from different cultures and ethnic groups to create shared meanings. The concern of this study is the intercultural communicative competence which has been described as an aspect of communicative competence which refers to the speaker's ability to interpret messages and to negotiate meaning with other speakers within a particular speech community (Lázár, 2003; Savignon, 2001).

Gómez (2012) describes intercultural communicative competence as the speaker's ability to interact effectively with people from other cultures that he/she recognizes as being different from his/ her own. Abbe, Gulick, and Herman (2007) aver that intercultural competence has cognitive, behavioural, and affective components that enable individuals to adapt effectively in multicultural environments. Such competence involves the ability to communicate effectively and appropriately with people of other culture and people with cross-cultural communicative competent are able to understand and tolerate cultures that are foreign to them.

Without a conscious approach to teach intercultural competence in a multicultural context, any effort towards the attainment of intercultural competence will end up a façade. The survival and transfer of culture from one generation to the other has been largely through education. Education remains a potent national tool to overcome create cultural awareness, eradicate cultural bias and foster intercultural competence in the 21 st century within and outside the classroom. There are certain subjects that are taught within the school curriculum that can be used to enhance intercultural communicative competence and literature-in-English is one of such subject areas. This is the very reason why this paper considers education as the most effective tool to enshrine intercultural communicative competence in a multilingual/multicultural nation like Nigeria.

Scholars (Adesuyi, 1991; Amuseghan and Momoh, 2013) have described literature-inEnglish as a school subject that is capable of exposing readers to other peoples' customs and cultural practices. Unlike several other school subjects, literature-in-English can be engaged as a tool for propagating cultural values and ideas, and the development of literary 
competence. However, apart from the fact that instruction in Literature-in-English enhances the students' general competence in the English language, it can also be used to foster intercultural communicative competence. Literature-in-English should not only be taught in schools for therapeutic and linguistic purposes but also for other functions such as the creation of cultural awareness, moral development and fostering of intercultural competences.

Amuseghan and Momoh (2013) submit that the teaching of literature-in-English reflects the customs, tradition, culture, religion and the norms of any given society. Therefore, there Nigeria can maximize the benefits of making use of literature-in-English to project different cultures and foster intercultural competence in the students. By implication, the teaching and learning of literature-in-English should be used to foster intercultural communicative competence in a multilingual/multicultural nation like Nigeria. It is expected that this will promote national unity and civil tolerance among the diverse ethnic groups in Nigeria. The purpose of this study is to discuss how to foster students' intercultural communicative competence within Nigerian context through quality instruction in literaturein-English.

\section{Discussion}

\section{Literature-in-English: A tool for fostering intercultural competence in Nigeria}

In recent times, there has been an increase in the spate ethnic-related violence and religious/cultural insurgency activities in Nigeria. Ajitoni (2014) avers that various associations which cut across the different ethnic and cultural groups have been formed in Nigeria in order to form a common front in the defence of their culture and ethnic interests. The formation of these ethnic militia groups has led to new levels of intercultural awareness that now determines economic, religious and political considerations in Nigeria. The activities of these ethnic militia groups have increased agitations for resource control, cultural identity and a corresponding interplay of forces that both encourage and discourage accommodation and understanding among different peoples in Nigeria (Ajitoni, 2014). Some of these ethnic/culture-biased groups are Miyetti Allah Cattle Breeders' association (MACBAN), Odua Peoples' Congress (OPC), Arewa Youth Forum (AYF), Movement for the Emancipation of the Niger Delta Region (MEND), Ijaw Youth Council (IYC), and Indigenous People of Biafra (IPOB).

Most of these ethnic-cultural groups were formed basically to promote ethnic/cultural identities and 'protect the interests' of the ethnic nationalities that they represent. Activities of some of these ethnic-biased groups to issues that they consider unfavourable to their interest have included threats, protests, wanton destruction of lives and properties, civil demonstrations, bombings, kidnapping of expatriate workers, and vandalism of public installations. Notably, agitations by members of IPOB in South-East Nigeria have taken a dangerous turn with the open declaration of threats to secede from Nigeria to Biafra. Similarly, there has been increase in deadly attacks and clashes between Fulani herders and farmers across Nigeria concerning the invasion and conversion of farmlands to grazing fields for cattle.

To stem the tide of the activities of these ethnic militia groups, the Nigerian government has introduced measures such as the clean-up of Ogoni Land, setting up of the Niger Delta Development Commission (NDDC), concession of portions of land to herders as cattle colonies and so on. In spite of the numerous interventions meant to integrate the different ethno-cultural groups into the Nigerian national life, cultural diversity has continued to divide Nigeria along ethnic interests both politically and economically. For example, 
Ajitoni and Salako (2012) lament the inadequacies in the knowledge of intergroup cultures and relations. According to these scholars, such 'inadequacies' are responsible for most of the ethnic-related crises in Nigeria.

In a multilingual/multicultural terrain like Nigeria, there is always a constant threat of dominance from cultures perceived to be more popular or civilised against the seemingly 'lesser cultures'. Thus, Ajiboye (2010) and Ajitoni (2014) averred that it is very important for people irrespective of their language, tribe or ethnicity (either major or minor) to maintain their cultural identity by preserving, protecting, and defending their culturally shared values. Ajiboye (2010) opines that factors such as geographical location, economic advantage, abundance of natural resources and education often create inequalities among the different cultures and place some cultures above others. Cultural dominance or suppression has led to cases of prejudice and complaints of marginalization against cultural practices that appear to fall within the influence of the more popular ethnic groups or cultures.

There is need for serious efforts to ameliorate culture-based conflicts (between the 'larger cultures and 'smaller cultures') in a multicultural nation like Nigeria. Therefore, education must be engaged as a tool to inculcate intercultural awareness, tolerance and competence in the citizens. Ajitoni (2011:206) avers that 'learners should be taught to respect the ways people in any culture communicate with each other, taking into account the conventions of greetings, of conventional structure and features of non-verbal behaviour.' One of the school subjects that can be used to teach and foster intercultural competence in Nigeria is literature-in-English. Literature is taught as part of the curriculum for English studies upper basic school and as literature-in-English which is a compulsory subject for students offering arts-related courses in the senior secondary schools in Nigeria.

Instruction in literature-in-English at the senior secondary school level cuts across the three genres of literature and the literary appreciation of the recommended texts in preparation for the final year examination. According to Labo-Popoola (2010), any learner that is thoroughly exposed to the cultural elements of literature will be fully integrated into his culture as well as other people's culture. In spite of the potentials inherent in the use of literature-in-English to teach intercultural competence, instructional procedures in most schools as far as the subject is concerned has been limited to textual reading and analysis across the genres with emphasis on the theme, characterisation, setting, tone, mood, diction, and general literary appreciation. Similarly, the different examination bodies usually often restrict their questions to content-based questions on the theme, character sand diction in the text.

Emphasis has been on textual reading and analysis because the focus of instruction is to prepare learners for success in literature-in-English examination and not to build intercultural competence. Learners are made to read the prescribed texts but little or no attention is given to the cultural aspects of the texts in the process of instruction except culture is one of the themes to be considered in the text. Fakeye (2011) avers that students do not often understand the cultural background of most prescribed literary texts because the cultural experiences encountered in the text are usually alien to them. However, it is possible to promote intercultural communicative competence in a multicultural classroom through effective teaching of literature-in-English.

Literature, in its widest sense, is an expression of a people's way of life which can cover the past, present or future. Gómez (2012) suggests that all kinds of reading materials are subtly loaded with different experiences of cultural expression because all writings are products of a particular community or people's cultural content. Olsen (2018) describes literature as a useful tool in building intercultural competence because it exposes learners to 
different cultures that they are unlikely to encounter within the four walls of the classroom. This is because literature gives the learners insight into the way of life or cultural experiences of people from different climes and cultural backgrounds. Tomlinson and Masuhara (2004) opine that intercultural competence can be achieved through an experience of the culture, either by direct contact with a culture or indirectly through films, music or literature. Learners can neither appreciate nor understand the concept of cultural differences without consciously learning it in the literature-in-English classroom. But Kramsch (2001) notes that most teachers are hesitant to use literary texts to facilitate intercultural competence because they are believe that the approved or recommended texts should only be read for their general interest and for their information value.

Olsen (2018) posits that the influence of language and culture on each other makes the knowledge of culture and language central for the development of intercultural competence. Kramsch (2001) recommends the use of different text types from conventional recommended texts to other literary texts that can offer learners the opportunity to access and interact with other cultural experiences that are not primarily theirs. Fenner (2011) states that the purpose of studying literary texts in school is often not primarily to portray a culture, rather, the readers come in contact with the culture through an understanding of the characters. Amer (2003) argues that literature can be employed to develop and promote students' intercultural competence in a multicultural society.

Effective teaching of the cultural elements in the prescribed texts for literature-inEnglish will foster intercultural competence in the Nigerian context. González Rodríguez and Puyal (2012) note that the selection of literary text to be studied in class should be carefully arrived to provide learners with opportunities to develop their capacity for critical analysis of foreign cultures and foster affective response to other people's attitudes and values. LaboPopoola (2010) opines that literature helps learners to develop their understanding of other people's culture, make them aware of the differences in cultures and enables them to tolerate or understand other peoples' culture. If the goal of teaching literature was to inculcate intercultural communicative competence in students, the choice of literary text should be made based on the cultural elements in the text at all levels of instruction. (Gómez, 2012)

Similarly, Thanasoulas (2001) suggests that exposure to literary texts can boost language competence in a second or foreign language classroom and help to define and redefine students' cultural values by exploring and interpreting the assumptions and beliefs of the target culture. The author, central theme, plot and other similar considerations should not be the only criteria for the selection of literary texts to be studied in a literature classroom when inculcating intercultural communicative competence is the objective of the instruction. The teacher should make efforts to expose learners to the cultural elements in the text and encourage tolerance by emphasising cultural diversity. Gómez (2012) submits that the selection of literary texts in a multicultural classroom should be structured to project diversity in culture than canonical works.

Further still, Labo-Popoola (2010) posits that effective teaching of literature is capable of fostering cultural assimilation or acculturation, language development and competence, conflict resolution, a good liberal education and development of desired and desirable attributes. Bredella (2003) and Corbett (2010) have stressed the importance of using literature to foster interpersonal and intercultural attitudes or skills that can enhance tolerance towards other people's culture. To accomplish the foregoing tasks, the teaching of literature-inEnglish in multicultural/multilingual Nigerian context must go beyond the mere reading and analysis of the prescribed texts. 
Ajitoni (2014) argues that it is very difficult to achieve intercultural competence in Nigeria because of the multicultural status of the Nigerian classroom. Ajitoni (ibid: 209) states: Cultural differences create dissimilar meanings and expectations that require even greater levels of communication skill. These dissimilar meanings and expectations have resulted in various obstacles to intercultural competence in Nigeria.

Ajitoni also identified some of the factors that impede intercultural competence in Nigeria as ethnocentrism, stereotyping, prejudice, discrimination, ethnicity/nepotism, dominance and subordination, and lack of knowledge, motivation, and skill. It is possible to successfully overcome the different problems associated with ethnicity and cultural prejudice in Nigeria through a paradigm shift in planning and lesson delivery in literature-in-English. In a multicultural literature classroom, both teachers and their students must demonstrate commitment to learn about other people's cultures without bias.

In addition, building intercultural competence in Nigeria requires that the teacher should be devoid of ethnocentrism. The teacher must be willing to seek new knowledge about the cultural background and setting of the prescribed text. Apart from the knowledge of the characters, themes, plot, and other aspects of the text, the teacher must be able to effectively translate the cultural elements in the plot. The teaching of literature-in-English in a multicultural classroom should be culture-based, balanced and free of any form of cultural stereotype, sentiment or prejudice on the part of the teacher. Studying the cultural background of a text with historical perspective prior to the reading and analysis of the literary content will facilitate and enrich learning experience in a multicultural classroom.

González Rodríguez and Puyal (2012) develop a unique framework to promote intercultural competence through the use of multicultural literary texts. The study presented a frame for integrating literary texts into Foreign Language Teaching (FLT) with intercultural skills and competencies in a systematic, natural way. The study found that literary texts can be used to enhance intercultural communicative competence especially in the area of gender roles. An understanding of the underlying culture to which a text can be classified will further aid the comprehension and retention of the text. For example, the understanding of the cultural role that gender plays in the Ashanti Tribe of Ghana can be used to explain the insistence of Pokuwa's mother to see her children in Asari Konadu's A woman in her prime.

Providing students with a culture-based approach to instruction in Literature-in-English creates culture awareness and builds their capacity to tolerate the cultural practices of other people. Also, students will become better informed about the similarities and differences that exist between their culture and that of the other ethnic nationalities within and outside Nigeria. The use of culture-based instructional approach in literature-in-English will bring about deeper understanding of the text as well as foster intercultural competence in the classroom. Students would not only know the thematic content of the plot, but they will also understand how the culture (of the writer or the setting) of the literary text underlies the development of the plot.

For instance, when teaching the plot of the Death and the King's Horseman by Wole Soyinka, an explanation of the cultural background of the Old Oyo Empire and the role of the 'Eleshin Oba', a high ranking chief that must willingly take his own life to escort the king to the great beyond when he dies, will help the students to appreciate the plot the more. Also, the knowledge of the cultural situation at the time of the event in the plot based on the setting of the play will further aid the comprehension of the plot and thematic elements in the play. This will also foster intercultural awareness and competence within the classroom. Several culture-based concepts, myths, customs and traditions can be effectively taught to students who are not from the culture in a multicultural classroom through literature-in-English. 
Another example is about the 'Osu' (a community of people that have been ostracised) in South-East Nigeria. Making use of a culturally rich text such as Achebe's Things Fall Apart, the teacher can effectively educate a multicultural class on the concept of 'Osu' in the South Eastern part of Nigeria. Also, considering the cultural basis for the killing of Ikemefuna (a boy that grew up in his household and has accepted him as a father) by Okonkwo will expose the learners/readers to the gender roles and societal expectations of the different genders in the Ibo community. An understanding of the cultural history and background of the ibos (South-East Nigeria) will aid students' understanding of the novel by Chinua Achebe and also foster intercultural competence, awareness and communication.

\section{Conclusion}

The importance of intercultural competence in a multicultural society like Nigeria cannot be overemphasised. There is a need to build respect for other people's culture and eradicate ethnocentrism and culture prejudice across Nigeria. Several attempts such as the convocation of a national conference, amnesty programme for the Niger Delta militants, provision of cattle colonies in the parts of Central and Southern Nigeria for herders, and the federal character principle, by the past and present Nigerian governments to build national unity and cultural integration have not yielded much result. Cultural diversity which should be a source of strength now threatens the unity of Nigeria because intercultural competence is being prosecuted outside the classroom. Therefore, this paper explains the viability of fostering intercultural communicative competence in Nigeria through the instrumentality of literature-in-English in multicultural classroom.

In conclusion, the teaching of literature-in-English in schools should not be limited to the reading and analysis of the prescribed texts. Teachers should ensure that the cultural background of each text should be taught and discussed with the students before the reading and analysis of the text. Effective teaching and learning of literature-in-English can foster intercultural competence, cultural awareness, tolerance and communicative competence in the multicultural Nigerian context.

Based on the discussions in this paper, the following recommendations were made:

1. For the sake of national unity in Nigeria, the status of literature-in-English should be upgraded to become one of the compulsory (or core) subjects in the Nigerian school system.

2. Instruction in literature-in-English should go beyond textual reading and analysis, the rhetoric of plot, theme and other literary elements of appreciations to the analysis of the historical and cultural background of the selected literary text.

3. The criteria for the selection of literary text to be studied in literature should include the cultural experiences and orientations of the text.

4. There is need for training and retraining of language and literature teachers to deliver the mandate of teaching to achieve intercultural competence as against teaching for the purpose of academic success in examination. 


\section{References}

Abbe, A., Lisa, M.V., and Herman, J.L. and U.S. Army Research Institute for the Behavioural and Social Sciences. 2007. Cross-cultural competence in army leaders: A conceptual and empirical foundation. Arlington, Va: U.S. Army Research Institute for the Behavioural and Social Sciences, Leader Development Research Unit. DOI: https://doi.org/10.21236/ada475798

Adesuyi, A. 1991. The relationship between students' exposure to literature-in-English and the English language. Obafemi Awolowo University, Ile-Ife.

Ajiboye, J.O. 2010. Social Studies Education in Nigeria and Emerging Curricular Issues. ADCOED Journal of Social Studies. Vol. 1:1.

Ajitoni, S.O. 2014. Enhancing Nigerian students' intercultural competence and achievement in social studies through outdoor activities. Journal of Language and Cultural Education, 2(2). P 205-217.

Ajitoni, S.O. and Salako, E.T. 2013. Effects of cooperative learning and field trip strategies on secondary school students' knowledge of and attitude to multiculturalconcepts in Social Studies. Journal of Education and Practice. Vol.4(22), pp 35-42. Retrieved online 5th Decenber, 2019 from www.iiste.org

Amers, A. (2003). Teaching EFL/ESL literature. The Reading Matrix, 3(2) 63-73.

Amuseghan, S. A. and Momoh, A. O. 2013. Enhancing students' performance in the English language through Literature-in-English in the secondary schools. Educational Research and Reviews. Academic Journals Vol. 8 (24). P 2242-2250.

Barrett, M., Byram, M., Lazar, I, Mompoint-Gaillard, P., and Philippou, S. (2014). Developing intercultural competence through education. Council of Europe Pestalozzi Series, No 3. Council of Europe Publishing.

Blench, R. and Dendo, M. 2003Position paper: the dimensions of ethnicity, language and culture in Nigeria. Nigeria: Drivers of Change. Component Three - Output 28. Prepared for DFID, Nigeria (Final Report). Retrieved online 29th July, 2015 from http://www.rogerblench.info/RBOP.htm

Bredella, L. 2003. For a flexible model of intercultural understanding. In Intercultural experience and education, ed. G. Alfred, M. Byram and M. Fleming, 31-49. Clevedon: Multilingual Matters.

Corbett, J. 2010. Intercultural language activities. Cambridge: Cambridge University Press.

Fakeye, D.O. 2011. Causes of declining enrolment in Literature-in English classroom. Gestet Voix, (5), 34-42.

Fenner, A.B. 2011. Litteraturens rolle i utviklingen av interkulturell kompetanse. Communicare, No. 1. Halden: Fremmedspråksenteret.

Gómez, L.F.R. 2012. Fostering intercultural communicative competence through reading authentic literary texts in an advanced Colombian EFL classroom: A constructivist perspective. A pedagogical research approved by the Department of English at Illinois State University, USA, as part of the requirements for the completion of the $\mathrm{PhD}$ program in English Studies. PROFILE Vol. 14, No. 1, April 2012. ISSN 1657-0790. Bogotá, Colombia. Pages 49-66

González Rodríguez, L.M.and Puyal, M.B. 2012. Promoting intercultural competence through literature in CLIL contexts. ATLANTIS Journal of the Spanish Association of Anglo-American Studies 34.2 (December 2012): 105-24

James, 1968. Language habits and the early introduction to Literature. Zaria: ABU Press. 
Kramsch, C. (2001). Context and culture in language teaching. Oxford: Oxford University Press.

Labo-Popoola, S.O. 2010. The place of literature in the teaching of English language as a second language. The Social Sciences Vol. 5 Issue 1. Pg 49-54. Retrieved on 22nd July, 2018 from http://www.medwelljournals.com/fulltext/?doi=sscience.2010.49.54

Lawal, S. O. 2019. Impact of Nigerian Pidgin English on senior secondary school students' competence and performance in English composition in military and paramilitary schools in Ibadan. B.A Project submitted to English Department, National Open University of Nigeria.

Lázár, I. 2003. Incorporating intercultural communicative competence in language teacher education. Strasbourg: European Centre of Modern Languages - Council of Europe Publishing.

Lustig, M. W. \& Koester, J. 1996. Intercultural competence: Interpersonal communication across culture. 2nd Ed. New York: Harper Collins College Publishers.

Olagbaju, O.O. \& Awosusi, E.O. 2019. Herders-Farmers' Communal Conflict in Nigeria: An Indigenised Language as an Alternative Resolution Mechanism. International Journal of Multidisciplinary and Current Research Vol.7 (Sept/Oct 2019 issue) pgs 615-623. Available at: http://ijmcr.com. DOI: https://doi.org/10.14741/ijmcr/v.7.5.3

Olagbaju, O.O. 2014. Multilingual education in Nigeria: Policy provisions, reality on ground, challenges and solutions. Journal of Education and Practice Vol.5, No.6, February, 2014. Pp 66 - 73. www.iitse.org

Olsen, C.N. 2018. Promoting intercultural competence through literature and film: The outsiders and its adaptation. MASTEROPPGAVE, Master i fremmedspråk i skolen Avdeling for økonomi, språk og samfunnsfag May 2018

Savignon, S. (2001). Communicative language teaching for the twenty-first century. In M. Murcia (Ed.), Teaching English as a second/foreign language (pp. 12-28). Boston, MA: Heinle \& Heinle.

Thanasoulas, D. 2001. The importance of teaching culture in foreign language classroom. Radical Pedagogy. Retrieved online 27th July, 2015 from http://radicalpedagogy.icaap.org/content/ issue3_3/7-thanasoulas.html

Tomlinson, B. and Masuhara, H. 2004. Developing cultural awareness. Met 13.1: 1-7. 